\title{
FLIPPED CLASSROOM TECHNOLOGY AND ITS IMPLEMENTATION AT VARIOUS LEVELS OF HIGHER EDUCATION
}

\author{
M.V. Tsytovich, Maria.Tsytovich@gmail.com, \\ G.F. Boronenko, gboronenko@yandex.ru, \\ O.V.Yakusheva, iow74@mail.ru \\ South Ural State University, Chelyabinsk, Russian Federation
}

\begin{abstract}
The fourth industrial revolution influences the system of education requiring abilities and competencies that go beyond what has traditionally been taught in the classroom. The main concern is the social nature of learning and the ability to collaborate using digital technologies. It also results in some general shifts in the world of learning - lifelong learning - from childhood, to continuous learning in the workplace. Foreign language as an academic subject has a great potential to meet the needs of industry 4.0 as it is taught at all levels of education. There are a lot of modern technologies of teaching languages: teaching in cooperation, project method, modular and blended learning. In this article we will focus on the Flipped classroom technology at different levels of education: bachelor, master, postgraduate training. The advantages and limitations of using this method at different levels are revealed. We provide an overview of information technologies that can be used to implement this method. Guidelines are given on how to ensure the technological continuity of the educational process, using the Flipped classroom, to develop students ' readiness for different ways of knowledge transfer. The authors describe the flipped class model and experience of using the flipped classroom technology teaching English at bachelor's, master's and advanced training courses at the South Ural State University.

Keywords: lifelong learning, Flipped classroom, levels of education, blended learning, technological continuity.
\end{abstract}

Problem statement. Every person has a lot of memories associated with school years or studying at the university and the typical picture is how you are sitting in the classroom and the teacher is explaining something, but you barely hear: you stare at the ceiling or the window dreaming about something. This is often the case in a traditional model of the educational process the center of which is a teacher presenting information, giving out assignments, and learning is the student's own deal. After class students spend a great amount of time doing homework, and if he has difficulties, he may stop doing it at all or start cheating. "In fact, a study done observing 9th-12th graders found that students spent an average of 38 hours a week doing homework" [1]. This is a huge investment of time not only for the student, but also for the teacher, who constantly prepares tasks, checks and evaluates them. This model can be effective, but it is very teacherdependent and the main drawback is that the student remains a passive recipient of information, rather than an active participant in his own process of learning. The idea of enhancing the educational process is not new. It was expressed throughout the entire period of the formation and development of pedagogy as a science.
In the history of pedagogy, one can trace the confrontation of two opposite views: one of them denies the activity of the student, the other considers it necessary for the development of personality and effectiveness of the educational process [12]. Nowadays there is a need to redefine the role of the teacher and the student in the education system and one of the solutions proposed by scientists and practitioners is the technology of the flipped class appeared within the activity based approach and blended learning.

Problem Background. The activity based approach implies the use of such system of methods, which is mainly aimed not at the presentation of ready-made knowledge and its reproduction, but at the independent acquiring of knowledge by students in the process of cognitive activity [31]. L.S. Vygotsky emphasized that personal development in the educational process occurs only in the course of doing something [45].

Contributions to the development of the active learning methods classification were made by Yu.S. Arutyunov, M.M. Birshtein, N.V. Burkov, A.A. Verbitsky, S.R. Gidrovich, R.F. Zhukov, V.M. Efimov, L.N. Ivanenko, V.F. Komarov, A.L. Livshits, V.I. Marshev, Yu.M. Porkhovnik, V.I. Rybalsky, T.P. Timofeevsky, and 


\section{Непрерывное образование в течение жизни}

others $[6,19,31]$. The most famous classification of active learning methods is the one proposed by A.M. Smolkin [35]. He distinguishes between imitative methods of active learning and nonimitative. Simulation methods are divided into game and non-game ones. Gaming includes conducting business games, game design, etc., and non-gaming ones - analyzing specific situations, solving situational problems, etc.

The educational process now has a tendency to shift from a teacher-centered to studentcentered educational environment. The model of the flipped classroom meets this need. The main goal of a flipped classroom is to enhance student learning and achievement by reversing the traditional model of a classroom.

The popularity of this approach can be explained by a number of reasons. First of all, the traditional model is too inert; it entered into the brain of both teachers and students. Teachers cannot refuse the "sage on the stage" model and try the "guide on the side" one, while students just keep waiting. Therefore, we need something special to make the difference and the flipped classroom approach seems brand new and quiet revolutionary.

Secondly, the rapid development of new technologies makes it possible to make educational content accessible, as modern LMS allows sharing materials in audio, video and text format and provide interaction between all participants of the educational process.

There is no single definition of inverted class technology, since in primary school, in high school and university, this technology will be applied differently and the inverted class will look different. The pioneers in the application of technology Jon Bergmann and Aaron Sams believe that every teacher before applying this approach must answer the question: What is the best use of your face-to-face class time? [2]. And since each teacher will answer this question in different ways, there cannot exist a unified definition of the notion of a flipped classroom. Many authors have been investigating this issue. There are many definitions regarding flipped classroom in literature. According to Bishop and Verleger $[4,5]$ flipped classroom is a student-centred learning method consisting of two parts with interactive learning activities during lesson and individual teaching bases directly on computer out of lesson. Mull [27] defined it as a model that provides students prepare themselves for the lesson by watching videos, listening podcasts and reading articles. Although there is no one definition but many researchers note that in this model, the roles of the teacher and the student change. The role of the teacher implies: Creating learning condition based on questioning [11]; Instead of transferring knowledge directly, being a guide to make learning easy [17]; Making one to one interaction with students [10]; Correcting misunderstandings [33]; Individualizing learning for each student [34]; Using technological equipment suitable for learning condition [14]; Creating interactive discussion conditions [24]; Increasing participation of students [23]; Providing feedback by using pedagogical strategies [26].

In flipped classroom approach student transforms from passive receiver of knowledge to active promoter of knowledge. In this approach the roles of students are the following: Taking their own learning responsibilities [42], Watching lecture videoas before the course and preparing for the course by using learning materials [2]; Learning at his own learning speed [3]; Making necessary interactions with his teacher and friends, taking and giving feedback [41].; Participating discussions within class [29]; Participating team working [13].

Summarizing, we can distinguish the following distinctive features of this approach: Flipped learning is a pedagogical approach in which the conventional notion of classroombased learning is inverted, so that students are introduced to the learning material before class, with classroom time then being used to deepen understanding through discussion with peers and problem-solving activities facilitated by teachers [8].

The Advantages and Limitations

of Flipped Classroom Approach

Scientists highlight many advantages of a flipped class. The potential of this approach is in the following:

1. The student has the opportunity or he has to take the responsibility for the results of his education. There is an opportunity to work at your own pace.

2. The student becomes the center of the educational process, learns to interact and cooperate with classmates under the guidance of a teacher.

3. Classes and their content are becoming more accessible for both students and their parents even if the teacher is busy or the student misses due to illness or participation in competitions [15].

4. The educational process becomes more efficient in terms of time consumption, since the 
student spends less time on the task. (38 hours per week compared to $10 \mathrm{~min}$. Video), and the teacher will spend less time on checking [13].

5. Students get help and support performing complex tasks that require higher-order thinking. Though some researchers consider this feature disadvantage - criticisms include reduced opportunity for self-directed critical thinking [18].

6 . The teacher has more time available for personal contact with students in the classroom.

7. There is an opportunity for the implementation of individual and differential approaches adapted to their cognitive speed [19].

8. Creates an atmosphere where learning, rather than teaching, is the goal.

9. The benefit of this approach is its flexibility - i.e. the teacher himself decides which classes he wants to flip or flip the whole course of study on the subject.

10. Improve the relationship between teacher and student and between students within the group [20].

However, a number of scientists and teachers are skeptical about the new model and note its weak points:

1. There is no guarantee that all students will study the necessary materials at home [25].

2. It increases the time spent by the teacher to prepare for classes, for video recording.

3 . The time spent by a student in front of a computer monitor increases [26].

4. This model does not prepare for passing tests [28].

5. Internet and computer and other devices and gadgets are required [30].

6 . It is necessary to explain parents the peculiarities of the new approach.

7. The importance of the teacher in the educational system is reduced and the teacher can gradually be replaced by a computer.

8. It requires substantial material expenses.

But it seems that the proponents of this approach have their own counter-argument or solution for the problems and the arguments of the opponents. Solutions are found in the course of active practical application of the approach and the development of new information technologies. In the past, teachers spent a lot of time and money creating video tutorials for their courses. Today there are free or inexpensive programs such as Screencast-O-Matic, Jing, and Snagit, which areeasy-to-use programs to create the instructional videos. There are practically no problems with access to the Internet and most stu- dents have the necessary electronic devices and educational institutions are well-equipped too.

\section{Technology of the flipped classroom}

The success of this approach largely depends on what information technology you use and how. Table 1 provides an overview of the existing technologies used by teachers at various stages of the flipped classroom implementation.

As can be seen from the table, there is a wide variety of application programs and other resources that can be used to implement this approach and if you want to use them it is not necessarily to be advanced computer user or tech savvy. You can start with the simplest ones, for example, save your PowerPoint presentation in video format and add voice accompaniment, and gradually make your flipped class more and more technological. Despite the fact that there is a large number of training videos on the Internet, most teachers prefer to create their own video and audio materials, as it is difficult to integrate the ready-made materials into their own course. While making a choice between one's own and a ready-made video one should remember that this approach is aimed at creating new, highquality, individualized relations between the teacher and students and within the group itself, and this is another way of mediating interaction and it should be as humanlike as possible. Whichever variant you choose, there is a great number of tips available in the Internet on how to create high-quality video as on this site [37].

Tips for Recording Video for a Flipped Classroom:

1. Select a simple and straightforward technology to record videos.

2. Start with a few lessons.

3. Don't make videos that are longer than $10-15$ minutes.

4. Write scripts before recording videos.

6. Include a summary of the lecture in your video and a hook for the next video.

\section{Flipped classroom models}

There are several models of the implementation of the flipped class technology. When choosing a particular model, it is necessary to take into account many factors: features of the target audience (age, level of language proficiency, etc.); technical equipment of the educational institution; teacher's willingness to use new technologies, etc. Careful analysis at the decision-making stage will allow to avoid many difficulties and failures at the implementation stage. 
Information technologies for Flipped classroom

\begin{tabular}{|c|c|c|c|}
\hline \multicolumn{2}{|c|}{ Content Creation Tools } & \multirow[b]{2}{*}{$\begin{array}{c}\text { Distribution } \\
\text { and hosting tools }\end{array}$} & \multirow[b]{2}{*}{ Video interaction software } \\
\hline $\begin{array}{l}\text { Ready made } \\
\text { solutions }\end{array}$ & $\begin{array}{c}\text { Instructional } \\
\text { video creation }\end{array}$ & & \\
\hline $\begin{array}{l}\text { PDFs, recorded } \\
\text { sounds, websites } \\
\text { such as } \\
\text { Khan Academy, } \\
\text { YouTube or Ted } \\
\text { Stanford } \\
\text { Academic Earth } \\
\text { Coursera } \\
\text { TeacherTube } \\
\text { Narrated Slides } \\
\text { Powerpoint or } \\
\text { Keynote presentations }\end{array}$ & $\begin{array}{l}\text { Screencasting } \\
\text { Such as Camtasia, } \\
\text { Screencast-O-Matic, } \\
\text { SnagIt, } \\
\text { and Office Mix Jing } \\
\text { (Windows or Mac) } \\
\text { Record It (Windows } \\
\text { or Mac) } \\
\text { Screenflow (Mac only) } \\
\text { QuickTime Player } \\
\text { (Mac only) } \\
\text { Adobe Presenter } \\
\text { Tablet Software } \\
\text { Radix Smart Class } \\
\text { Document Camera-Based } \\
\text { Solutions } \\
\text { Camera-Based Solutions } \\
\text { Animations } \\
\text { Adobe Voice (iPad only) } \\
\text { Go Animate } \\
\text { VideoScribe } \\
\text { PowToon }\end{array}$ & $\begin{array}{l}\text { YouTube, TeacherTube, } \\
\text { Screencast.com, Acclaim, } \\
\text { GoogleDrive. } \\
\text { school's learning manage- } \\
\text { ment system or website } \\
\text { examples of LMS } \\
\text { Moodle, Sakai, } \\
\text { Blackkboard, VersoApp, } \\
\text { Schoology, canvas, My Big } \\
\text { Campus, Haiku Learning, } \\
\text { Google Classroom }\end{array}$ & $\begin{array}{l}\text { Low Tech solutions } \\
\text { High Tech solutions: } \\
\text { Google Apps for Ed Learning } \\
\text { Management such as a Google } \\
\text { Form built-in quizzing feature } \\
\text { in LMS edu Canon or Zaption, } \\
\text { which will pause the vide } \\
\text { questioning app such as Verso } \\
\text { Apps which provide analytics } \\
\text { of student responses: } \\
\text { Techsmith Relay } \\
\text { Adobe Presenter 10 } \\
\text { MicroSoft Office Mix }\end{array}$ \\
\hline
\end{tabular}

Bergman describes the traditional model of an inverted class. A distinctive feature of this model is that the lessons are always given as lecture video format out of course period and the teacher never teaches lesson directly. Accordingly students are given opportunity to learn by discussing. Also, there is a significant redistribution of class time [3]. Clearly the difference in the distribution of time in a traditional and flipped class can be traced in Table 2 .

Comparison of within class activity periods of traditional approach and flipped classroom approach

\begin{tabular}{|l|c|l|c|}
\hline \multicolumn{1}{|c|}{$\begin{array}{c}\text { Traditional } \\
\text { classroom }\end{array}$} & Time & \multicolumn{1}{|c|}{$\begin{array}{c}\text { Flipped } \\
\text { classroom }\end{array}$} & Time \\
\hline Warm up & $5 \mathrm{~min}$ & Warm up & $5 \mathrm{~min}$ \\
\hline $\begin{array}{l}\text { Homework } \\
\text { checking } \\
\text { of previous lesson }\end{array}$ & $20 \mathrm{~min}$ & $\begin{array}{l}\text { Answering } \\
\text { lecture video } \\
\text { questions }\end{array}$ & $10 \mathrm{~min}$ \\
\hline $\begin{array}{l}\text { Teaching } \\
\text { of new subject }\end{array}$ & $\begin{array}{c}30-45 \\
\mathrm{~min}\end{array}$ & - & - \\
\hline $\begin{array}{l}\text { Exercises } \\
\text { or labarotory } \\
\text { applications }\end{array}$ & $\begin{array}{c}20-35 \\
\mathrm{~min}\end{array}$ & $\begin{array}{l}\text { Exercises } \\
\text { or laboratory } \\
\text { applications }\end{array}$ & $75 \mathrm{~min}$ \\
\hline
\end{tabular}

It is obvious that, with the traditional approach, most of the class time is spent on explaining, presenting new material, and when it is flipped - on a productive discussion. The model of a partially inverted class is a kind of traditional, but it is assumed that students can come to the class without watching the training video first.

IChen, et al added 3 structures (Progressive Activities, Engaging Experiences, and Diversified Platforms) to four structures of flipped classroom approach (Flexible Environments, Learning Culture, Intentional Content, and Professional Educators) and formed Holistic Flipped Classroom (HFC) model [9]. Holistic Flipped Classroom is a model that contains total of home, mobile and physical classrooms synchronously. A distinctive feature of this approach is that the entire educational space is considered as a class and therefore, what the student does is always monitored and he can always get help or feedback.

Results and discussion: Flipped classroom implementation model. In our opinion, it is important to describe the flipped classroom implementation model since at present only its scattered elements are used and we need to introduce it systematically, step by step taking into account the peculiarities of the educational system in Russia as a whole and the educational institution in particular.

We identified 3 levels or 3 stages of flipped class approach implementation as you can see 
in Fig. 1. The first stage - preparatory - corresponds to training for a bachelor degree. When students come to the university after 11 years of high school with traditional teaching model they are very passive and indifferent, they wait for everything to be explained to them. They are not ready for the degree of freedom that is granted to them, they are not capable of independent work and effective organization of their time. This is one of the main reasons for the large number of expelled students after the first year of study. Therefore, attempts to immediately apply the technology of the flipped class will be little effective and can even fail - it is necessary to introduce techniques and methods of active learning in the educational process gradually and consistently.

The aim of the educational process at this stage is to create conditions for the development of students' readiness for inverted education, which includes the student's readiness for independent study and research work and the willingness to take responsibility for the results of education $[43,44]$. So we are talking about student's

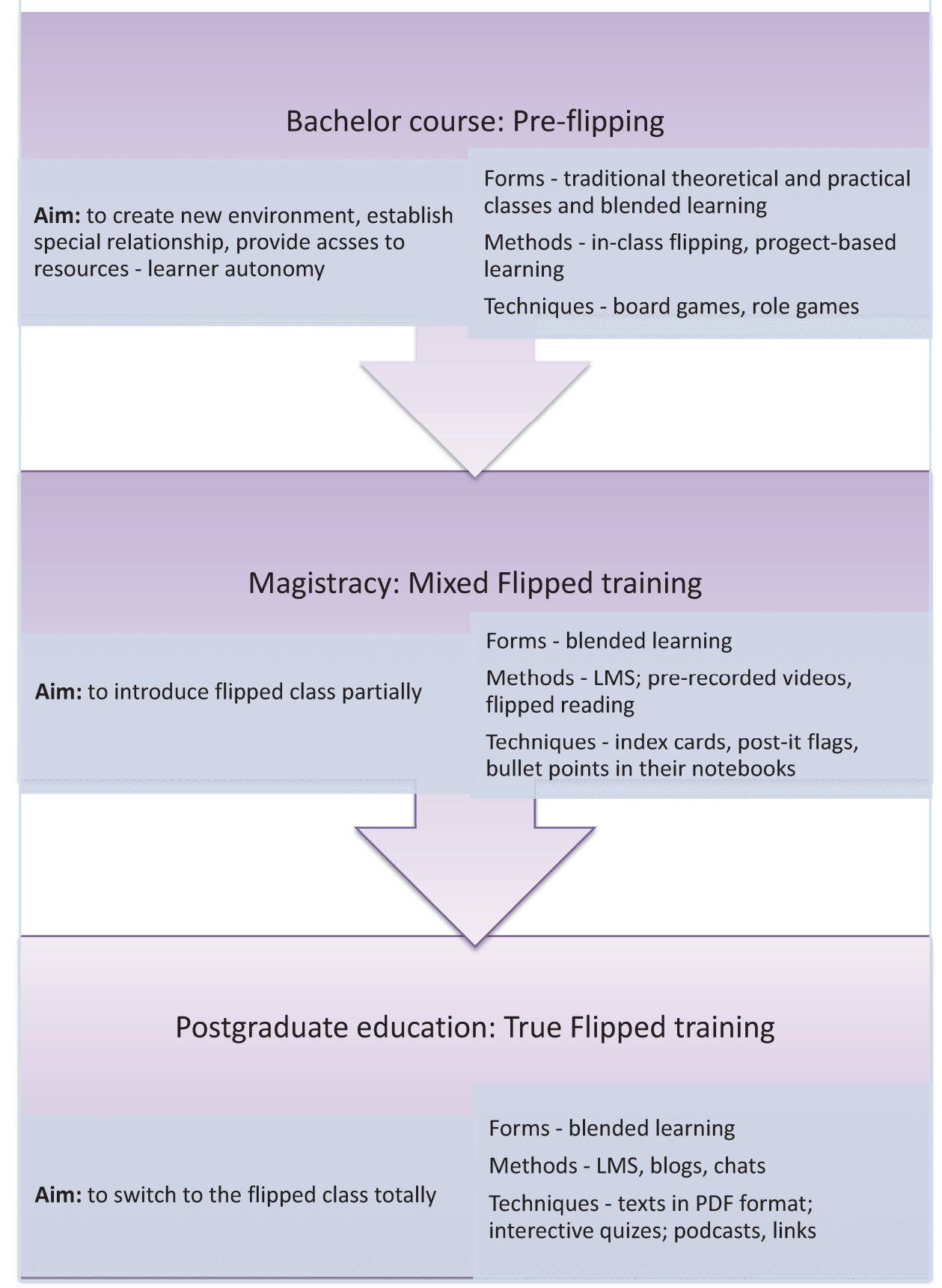

Fig. 1. Flipped classroom implementation model 


\section{Непрерывное образование в течение жизни}

autonomy. Autonomy is the ability to take charge of one's own learning. ... "Autonomy is a situation in which the learner is totally responsible for all the decisions concerned with his [or her] learning and the implementation of those decisions" [16].

By creating the conditions, we understand the organization of the subject-subject pedagogical interaction between the teacher and the student and between the students within the group, which helps create an atmosphere of trust and security. It also implies providing access to a variety of information and educational resources [21, 22].

Good practical tip at this stage for the teacher who wants to use the flipped class is the following: first choose a pedagogical model that transforms need to learn into want to learn, for example, the project based model, be really good at mastering this model and then think about how to support this model using flipped class technology.

There is one problem that is particularly relevant to this stage and that often stops teacher from using flipped class in fact there is no guarantee that students will watch the necessary video at home before class because of technical and personal problems. To solve this problem, it is proposed to apply the so-called in-class flipped class. Flipping the Flipped Classroom means that you record your lesson as if you were creating a flipped classroom, but then play it as the first part of the lesson [26]. This way everyone present at school had the chance to receive the full instruction in an equal manner and you would be able to refer back to the videos if necessary. Essentially it is putting the instruction back into the school day, but in a way that is efficient and differentiates for each student.

We should pay attention to one more problem at the preparatory stage. A recent study in the Journal of Educational Psychology showed that when researchers added a simple animated teacher character to a piece of digital multimedia, student performance improved [36]. Students were trying harder and understanding more when the material included a little humanity. The physical space of the audience has a powerful educational potential, as we establish contact with the audience through energy, enthusiasm, jokes, gestures, even the clothes we wear. Therefore, it is necessary to add humanity to the electronic materials that we prepare. Here are some tips:

1. Make the online members more visible as humans by posting photos.
2. Consider letting them talk instead of type using Ed. Voice Thread.

3. Expecting students to respond to each other's posts Humans respond to reciprocity. Students should experience the give and take of a real-world social interaction when they're working online.

The second stage is called the partially flipped class. The aim of this stage is to determine the level of students' readiness for this model correctly and, on the basis of this, the implementation of a flipped class to some extent. The teacher may decide to flip half of the lessons or up to $70 \%$ or $30 \%$, taking into account such factors as the features of the course and how well the educational process is equipped. The implementation of this phase occurs at the level of the magistracy. For this, the department of foreign languages has developed a fairly convenient set of teaching and learning materials. A course book consists of modules there isa sufficient number of exercises in each of the module and what is more important, questions for discussion that allow you to organize debates in the class. Each module has one or two videos that are supposed to be watched at home. The audience performs exercises on video and discussion of the content. You can also use cell phones to refresh the content of the video. In addition, online course support has been developed in the Moodle system. This LMS allows not only to share information resources, but also to organize the interaction of participants at all stages of the educational process.

We can also flip the reading and writing skills training. Practicing teachers are sharing their experiences. Students read in class 3-4 times a week for 2.5 weeks [32]. They must read actively, but get to choose their method: index cards, post-it flags, bullet points in their notebooks, etc. At home, students write on their blog using the Writing to Learn method. They have the freedom to craft posts on topics of their own choosing. Every day that they read in class, students blog about the experience at home. Advantages and novelty of this approach to teaching how to read:

1. They are independent readers and writers existing as autonomous learners.

2. They are evaluating complex texts and conveying intricate, multi-faceted information.

3. No longer just about impressing the teacher, their writing exists unto a larger audience: classmates, friends, and the blogosphere.

The third stage in this process is a pure flipped classroom. This corresponds to the level 
of postgraduate training and is suitable for use on add. Education and various refresher courses. The aim of this stage is to free up to the maximum the limited class time for discussing complex issues and solving practical problems [40]. An example of application is the course - "English language: research paper" - developed by the Electronic SUSU 2.0 developed in the Center of Academic Writing using the LMS of the Institute of Distant education called Electronic SUSU 2.0 [7].

This online course has the following structure: it is divided into 12 weeks; each week covers particular units of the course book. The week section comprises the following:

- Theoretical material in PDF format;

- Academic writing podcasts with PDF version;

- Vocabulary Activities;

- Additional video materials and links.

There is a quiz after each theoretical module. The test is a set of 20-25 multiple choice questions.

Educational process during the semester based on the model of the flipped class was organized as follows: the students studied all the theoretical part of the material at home independently, reading the materials presented in the course in PDF format, watching videos and performing small training tests based on the lesson material. It was also necessary to listen to podcasts for the widening of academic vocabulary and to do interactive vocabulary exercises. So, students came prepared to classes and felt more confident. This was especially appreciated by the students with a lower level of language proficiency [38]. During the classroom, complicated issues of the theory were discussed, and much attention was paid to practical assignments. The emphases was made on students' productive activity in the class such as: finding any possible mistakes in a piece of writing, paraphrasing sentences, putting punctuation in the paragraph, comparing the original and the revised version, various lexical and grammatical exercises. Much attention was paid to the academic texts analysis: work with particular articles and collections of articles. Via this learning platform, students provided their assignments for checking and proofreading [39].

At this stage, the role of the teacher in the audience is changed completely - he is no longer engaged in the presentation of new material. Even Salman Khan says that the teacher is now "liberated to communicate with their students and observes student construction of knowledge".
Conclusion and Future Work. The concept of a flipped class is quite simple and at the same time effective. Teachers will recapture instructional time that can be used to deepen learning. Student engagement will likely rise due to more personalized contact with information. And a richer culture of collaboration will emerge among students who learn to work together. Flipped learning means that teachers do less talking and more listening. In our opinion, a good teacher, no matter what discipline he teaches, seeks to move away from passive transfer of knowledge and create an educational environment to the development of critical thinking, where students will interact and cooperate freely, and the teacher will be there to help in solving complicated tasks. To do this, there are many educational technologies available and a flipped classroom is one of them. As can be seen from the model, the potential of the flipped class is not yet fully realized in the higher education system. Further developments include the creation of their own videos by the teachers to support their courses and the organization of effective interaction not only in the class but also out of it using new information and communication

\section{References}

1. 7 Things You Should Know About Flipped Classrooms. Available at: http://www. educause.edu/library/resources/7-things-youshould-know-about-flipped-classrooms (accessed 01.04.2019).

2. Bergmann J., Sams A. Flip Your Classroom: Reach Every Student in Every Class Every Day. International Society for Technology in Education Publ., 2012. 120 p.

3. Bergmann J., Sams A. Flipping for Mastery. Educational Leadership, 2014, vol. 71, no. 4, pp. 24-29.

4. Bishop J., Verleger M. Testing the Flipped Classroom with Model-Eliciting Activities and Video Lectures in a Mid-Level Undergraduate Engineering Course. Frontiers in Education Conference, 2013, pp. 161-163.

5. Bishop J., Verleger M. The Flipped Classroom: A Survey of the Research. ASEE National Conference Proceedings, 2013, vol. 30, no. 9, pp. 1-18.

6. Boronenko G.F. [Mind Map as an Independent Foreign Language Learning Method]. Nauka YuURGU. Materialy 68-y nauchnoy konferentsii [Science of South Ural State University. Materials of the 68th Scientific Conference], 2016, pp. 865-870. (in Russ.) 


\section{Непрерывное образование в течение жизни}

7. Bryan T., Shestakova L., Volchenkova K.N. A Center for Academic Writing at South Ural State University: Which Model to Choose? 8th International Conference on Education and New Learning Technologies, 2016, pp. 299-307.

8. Bryan A., Volchenkova K.N. Blended Learning: Definition, Models, Implications for Higher Education. Bulletin of the South Ural State University. Ser. Education. Pedagogy, 2016, vol. 8, no. 2, pp. 24-30.

9. Chen Y., Wang Y., Chen N.S. Is Flip Enough? Or Should We Use The Flipped Model Instead? Computers and Education, 2014, vol. 79, pp. 16-27.

10. Cohen S., Brugar K. I Want That... Flipping the Classroom. Middle Ground, 2013, vol. 16 , no. 4 , pp. $12-13$.

11. Desyat' pedagogicheskikh printsipov, kotorye okazhut samoe znachitel'noe vliyanie na obrazovanie $v$ blizhayshie gody [10 Principles to Have the Greatest Impact on Education in the Near Future]. Available at: http://www. edutainme.ru/post/innovation-teaching-2014/ (accessed 01.04.2019).

12. Dzhurinskiy A.N. Istoriya zarubezhnoy pedagogiki: uchebnoe posobie dlya vuzov [History of International Pedagogy: a Textbook for Colleges]. Moscow, Forum Infra-M Publ., 1998. $272 \mathrm{p}$.

13. Formica S.P., Easley J.L., Spraker M.C. Transforming Common-Sense Beliefs into Newtonian Thinking Through Just-in-Time Teaching. Physics Education Research, 2010, vol. 6, no. 2, pp. 1-7.

14. Fulton K. Upside Down and Inside Out: Flip Your Classroom to Improve Student Learning. Learning \& Leading with Technology, 2012, vol. 39, no. 8, pp. 12-17.

15. Hertz M.B. The Flipped Classroom: Pro and Con. Available at: https://www.edutopia. org/blog/flipped-classroom-pro-and-con-marybeth-hertz (accessed 27.06.2019).

16. Holec H. Autonomy and Foreign Language Learning. Oxford, Pergamon Press Publ., $1981.51 \mathrm{p}$.

17. Johnson L., Renner J. Effect of the Flipped Classroom Model on a Secondary Computer Applications Course: Student and Teacher Perceptions, Questions and Student Achievement. Unpublished. Diss. Doct. (Pedagogy). Louisville, 2012. $104 \mathrm{p}$.

18. Kakie tekhnologii izmenyat shkoly $v$ blizhayshie pyat' let? [What Technologies are Going to Change Schools in the Next Five
Years?] Available at: http://www.edutainme.ru/ post/horizon2014-schools/ (accessed 03.04.2019).

19. Kirlanov T.G. [Classification of Active Learning Methods in Higher Education]. Molodoy uchenyy [The Young Scholar], 2010, no. 4. Available at: https://moluch.ru/archive/15/1455/ (accessed 03.04.2019) (in Russ.)

20. Kolova S.M., Yaroslavova E.N. [Realization of Socio-Cultural Component in Foreign Language Education Content of Future Professional Preparation by Means of Information and Communication Technologies]. Applied Linguistics, 2014, vol. 2 (14), pp. 32-41. (in Russ.)

21. Kotlyarova I.O. [Model of the University Teaching Staff Readiness for International Cooperation]. Bulletin of the Chelyabinsk State Academy of Culture and Art, 2015, no. 2 (42), pp. 161-168. (in Russ.)

22. Kotlyarova I.O., Naydanova Yu.V. [Formation of the Personal Mobility in the System of Continuing Education: Review]. Bulletin of the South Ural State University. Ser. Education. Pedagogy, 2017, vol. 9, no. 2, pp. 6-26. (in Russ.)

23. Millard E. 5 Reasons Flipped Classrooms Work. Available at: https://web.archive. org/web/20121129121540/https://www.universit ybusiness.com/article/5-reasons-flippedclassrooms-work (accessed 27.06.2019).

24. Milman N. The Flipped Classroom Strategy: What Is It And How Can It Be Used? Distance Learning, 2012, vol. 9, no. 3, pp. 85-87.

25. Njie-Carr V.P., Ludeman E., Lee M.C., Dordunoo D., Trocky N.M., Jenkins L.S. An Integrative Review of Flipped Classroom Teaching Models in Nursing Education. Journal of Professional Nursing, 2017, vol. 33, no. 2, pp. 133-144. DOI: $10.1016 /$ j.profnurs.2016.07.001

26. Nolan M.A., Washington S.S. Flipped Out: Successful Strategies for Improving Student Engagement. Virginia Tech's Conference on Higher Education Pedagogy, 2013.

27. November A., Mull B. Flipped Learning: A Response to Five Common Criticisms. Available at: http://web.uvic.ca/ gtreloar/Articles/ Technology/flipped-learning-a-response-to-fivecommon-criticisms.pdf (accessed 29.06.2019).

28. O'Flaherty J., Phillips C. The Use of Flipped Classrooms in Higher Education: A Scoping Review. The Internet and Higher Education, 2015, vol. 25, pp. 5-95. DOI: 10.1016/j.iheduc.2015.02.002

29. Overmyer J. Flipped Classrooms 101. Principal, 2012, vol. 92, no. 1, pp. 46-47.

30. Ozdamli F., Asiksoy G. Flipped Class- 
room Approach. World Journal on Educational Technology: Current Issues, 2016, vol. 8, no. 2, pp. 98-105.

31. Piskunov A.I. Istoriya pedagogiki i obrazovaniya. ot zarozhdeniya vospitaniya $v$ pervobytnom obshchestve do kontsa XX v.: uchebnoe posobie dlya ped. ucheb. zavedeniy [History of Pedagogy and Education from the Beginnings of Mentoring in Primitive Society to the Late $20^{\text {th }}$ Century: a Textbook for Teacher Training Colleges]. Moscow, Sfera Publ., 2001. 512 p.

32. Semyonova A., Shatalova M. Moskovskie shkoly provedut "perevernutye uroki" [Moscow Schools to Give 'Flipped Lessons']. Available at: http://izvestia.ru/news/561316 (accessed 05.04.2019).

33. Schwartz M. The Flipped Classroom. Available at: https://www.ryerson.ca/content/ dam/lt/resources/handouts/flipped_classroom.pdf (accessed 01.05.2019).

34. Schmidt S.M., Ralph D.L. The Flipped Classroom: A Twist on Teaching. Contemporary Issues in Education Research, 2016, vol. 9, no. 1, pp. 1-6.

35. Smolkin A.M. Metody aktivnogo obucheniya [Active Learning Methods]. Moscow, Vysshaya Shkola Publ., 1991. 176 p.

36. Thompson T., Kanuka H. Establishing Communities of Practice for Effective and Sustainable Professional Development for Blended Learning. Effective Blended Learning Practices: Evidence-Based Perspectives in ICT-Facilitated Education: Evidence-Based Perspectives in ICTFacilitated Education, 2009, pp. 144-162. DOI: 10.4018/9781605662961.ch008

37. Tips for Recording Video for a Flipped Classroom. Available at: https://web.archive.org/ web/20150317193149/http://ctl.uga.edu/flipping/ video-tips (accessed 29.06.2019).

38. Tsytovich M.V. Pedagogical Assistance to "Lingva" Program Participants Professional Writing Formation at the Elementary Stage of Language Training. Bulletin of the South Ural
State University. Ser. Education. Educational Sciences, 2016, vol. 8, no. 2, pp. 41-47. (in Russ.) DOI: $10.14529 /$ ped 160206

39. Tsytovich M.V., Boronenko G.F. Teaching Academic Writing in a Flipped Classroom. Bulletin of the South Ural State University. Ser. Education. Educational Sciences, 2018, vol. 10, no. 2, pp. 59-65. DOI: $10.14529 /$ ped180208

40. Tsytovich M.V., Yakusheva O.V. Academic Writing Skills of University Teaching Staff Formation at the Pre-Intermediate Stages of Language Training. 9th Annual International Conference on Technology, Education and Development, 2016, pp. 8160-8165. DOI: 10.21125/iceri.2016.0869

41. Tucker B. Flipped Classroom: Online Instruction at Home Frees Class Time for Learning. Education Next, 2012, vol. 12, no.1, pp. 82-83.

42. Vladimirov A.V., Lebedev Yu.B. Metodika "perevernutogo klassa" $v$ realizatsii trebovaniy FGOS [The Flipped Classroom Approach as a Means of Implementing the Requirements of the Federal Learning Standards]. Available at: http://gov.cap.ru/SiteMap.aspx? gov_id=121\&id=1919130 (accessed 07.04.2019).

43. Volchenkova K.N. An Andragogical Approach to Forming Faculty Communication Competence in Foreign Language for International Activities. Bulletin of the South Ural State University. Ser. Education. Educational Sciences, 2015, vol. 7, no. 4, pp. 18-25. DOI: $10.14529 /$ ped 150403

44. Volchenkova K.N. Peer Observation as a Tool for Teacher's Professional Development and the Way to Increase the Quality of the Education Process. Bulletin of the South Ural State University. Ser. Education. Educational Sciences, 2016, vol. 8, no. 3, pp. 39-44. DOI: 10.14529/ped160304

45. Vygotsky L.S. Pedagogicheskaya psikhologiya [Educational Psychology], english translation: R. Silverman et al. CRC Press Publ., 1997. $416 \mathrm{p}$.

Received 29 May 2019 


\title{
ИСПОЛЬЗОВАНИЕ ТЕХНОЛОГИИ ПЕРЕВЕРНУТОГО КЛАССА НА РАЗНЫХ СТУПЕНЯХ ВЫСШЕГО ОБРАЗОВАНИЯ
}

\author{
М.В. Цытович, Г.Ф. Бороненко, О.В. Якушева \\ Южно-Уральский государственный университет, г. Челябинск, Россия
}

\begin{abstract}
Четвертая индустриальная революция оказывает влияние на систему образования, от которой требуется формирование таких умений и навыков, которые выходят за рамки того, что традиционно преподавалось в классе. Основными приоритетами являются социальная природа обучения и способность сотрудничать с использованием цифровых технологий. Это также приводит к некоторым общим тенденциям в сфере образования - обучение на протяжении всей жизни - к непрерывному обучению с детства до переподготовки на рабочем месте. Иностранный язык как учебный предмет имеет большой потенциал для удовлетворения потребностей индустрии 4.0, поскольку он преподается на всех уровнях образования. Существует множество современных технологий обучения языкам: обучение в сотрудничестве, метод проектов, модульное и смешанное обучение. В этой статье мы сконцентрируем внимание на технологии перевернутого класса на разных ступенях образования: бакалавриат, магистратура, послевузовское обучение. Выявлены преимущества и недостатки использования этого метода на разных уровнях подготовки. Предоставлен обзор информационных технологий, которые могут быть использованы для реализации этого метода. Приводятся рекомендации о том, как обеспечить технологическую преемственность образовательного процесса, используя перевернутый класс, чтобы развить готовность студентов к различным способам передачи знаний.

Авторы описывают модель реализации перевернутого класса и опыт использования технологии перевернутого класса для обучения английскому языку студентов бакалавриата, магистратуры и на курсах повышения квалификации в Южно-Уральском государственном университете.
\end{abstract}

Ключевые слова: непрерывное обучение, перевернутый класс, уровни образования, смешанное обучение, технологическая преемственность.

\section{Лumepamypa}

1. 7 Things You Should Know About Flipped Classrooms. - http://www.educause.edu/library/ resources/7-things-you-should-know-about-flipped-classrooms (дата обращения: 01.04.2019).

2. Bergmann, J. Flip Your Classroom: Reach Every Student in Every Class Every Day / J. Bergmann, A. Sams. - International Society for Technology in Education, 2012. - 120 p.

3. Bergmann, J. Flipping for Mastery / J. Bergmann, A. Sams // Educational Leadership. - 2014. Vol. 71, no. 4. - P. 24-29.

4. Bishop, J. Testing the Flipped Classroom with Model-Eliciting Activities and Video Lectures in a Mid-Level Undergraduate Engineering Course / J. Bishop, M. Verleger // Frontiers in Education Conference. - 2013. - P. 161-163.

5. Bishop, J. The Flipped Classroom: A Survey of the Research / J. Bishop, M. Verleger // ASEE National Conference Proceedings. - 2013. - Vol. 30, no. 9. - P. 1-18.

6. Бороненко, Г.Ф. Ментальная карта как самостоятельный метод изучения иностранного языка / Г.Ф. Бороненко // Наука ЮУрГУ: материаль 68-й научной конференции. - 2016. C. $865-870$.

7. Bryan, T. A Center for Academic Writing at South Ural State University: Which Model to Choose? / T. Bryan, L. Shestakova, K.N. Volchenkova // 8th International Conference on Education and New Learning Technologies. - 2016. - P. 299-307.

8. Bryan, A. Blended Learning: Definition, Models, Implications for Higher Education / A. Bryan, K.N. Volchenkova // Вестник ЮУрГУ. Серия «Образование. Педагогические науки». - 2016. - Т. 8, № 2. - P. 24-30.

9. Chen, Y. Is Flip Enough? Or Should We Use The Flipped Model Instead? / Y. Chen, Y. Wang, N.S. Chen // Computers and Education. - 2014. - Vol. 79. - P. 16-27. 
10. Cohen, S. I Want That... Flipping the Classroom / S. Cohen, K. Brugar // Middle Ground. 2013. - Vol. 16, no. 4. - P. 12-13.

11. 10 принципов, которые окажут наибольшее влияние на образование в ближайшем будущем. - http://www.edutainme.ru/post/innovation-teaching-2014/ (дата обращения: 01.04.2019).

12. Джуринский, А.Н. История Международной педагогики: учебник для колледжей / А.Н. Джуринский. - М.: Форум Инфра-М, 1998. - 272 с.

13. Formica, S.P. Transforming Common-Sense Beliefs into Newtonian Thinking Through Justin-Time Teaching / S.P. Formica, J.L. Easley, M.C. Spraker // Physics Education Research. - 2010. Vol. 6, no. 2. - P. 1-7.

14. Fulton, K. Upside Down and Inside Out: Flip Your Classroom to Improve Student Learning / K. Fulton // Learning \& Leading with Technology. - 2012. - Vol. 39, no. 8. - P. 12-17.

15. Hertz, M.B. The Flipped Classroom: Pro and Con / M.B. Hertz. - https://www.edutopia.org/ blog/flipped-classroom-pro-and-con-mary-beth-hertz (дата обращения: 27.06.2019).

16. Holec, H. Autonomy and Foreign Language Learning / H. Holec. - Oxford: Pergamon Press, 1981. $-51 \mathrm{p}$.

17. Johnson, L. Effect of The Flipped Classroom Model on a Secondary Computer Applications Course: Student and Teacher Perceptions, Questions and Student Achievement. Unpublished: diss. ... doct. ped. of sciences / L. Johnson, J. Renner. - Louisville, 2012. - 104 p.

18. Какие технологии изменят школь в ближайшие пять лет? - http://www.edutainme.ru/ post/horizon2014-schools/ (дата обращения: 03.04.2019).

19. Кирланов, Т.Г. Классификачия активных методов обучения в высшем образовании / Т.Г. Кирланов // Молодой ученый. - 2010. - №. 4. - https://moluch.ru/archive/15/1455/ (дата обращения: 03.04.2019).

20. Колова, С.М. Реализация соииокультурного компонента в содержании иноязычного образования будущей профессиональной подготовки средствами информационно-коммуникачионных технологий / С.М. Колова, Е.Н. Ярославова // Прикладная лингвистика. - 2014. T. 2 (14). - C. 32-41.

21. Котлярова, И.О. Модель готовности профессорско-преподавательского состава университета к международному сотрудничеству / И.О. Котлярова // Вестник Челяб. гос. академии культуры и искусства. - 2015. - №. 2 (42). - С. 161-168.

22. Котлярова, И.О. Формирование личностной мобильности в системе непрерывного образования: обзор / И.О. Котлярова, Ю.В. Найданова // Вестник ЮУрГУ. Серия «Образование. Педагогические науки». - 2017. - T. 9, №. 2. - C. 6-26.

23. Millard, E. 5 Reasons Flipped Classrooms Work / E. Millard. - https://web.archive.org/web/ 20121129121540/https://www.universitybusiness.com/article/5-reasons-flipped-classrooms-work (dama обращения: 27.06.2019).

24. Milman, N. The Flipped Classroom Strategy: What Is It And How Can It Be Used? / N. Milman // Distance Learning. - 2012. - Vol. 9, no. 3. - P. 85-87.

25. Njie-Carr, V.P. An Integrative Review of Flipped Classroom Teaching Models in Nursing Education / V.P. Njie-Carr, E. Ludeman, M.C. Lee et al. // Journal of Professional Nursing. - 2017. Vol. 33, no. 2. $-P$. 133-144.

26. Nolan, M.A. Flipped Out: Successful Strategies for Improving Student Engagement / M.A. Nolan, S.S. Washington // Virginia Tech's Conference on Higher Education Pedagogy. - 2013.

27. November, A. Flipped Learning: A Response To Five Common Criticisms / A. November, B. Mull. - http://web.uvic.ca/ gtreloar/Articles/Technology/flipped-learning-a-response-to-five-commoncriticisms.pdf (дата обращения: 29.06.2019).

28. O'Flaherty, J. The Use of Flipped Classrooms in Higher Education: A Scoping Review / J. O'Flaherty, C. Phillips // The Internet and Higher Education. - 2015. - Vol. 25. - P. 5-95.

29. Overmyer, J. Flipped Classrooms 101 / J. Overmyer // Principal. - 2012. - Vol. 92, no. 1. P. 46-47.

30. Ozdamli, F. Flipped Classroom Approach / F. Ozdamli, G. Asiksoy // World Journal on Educational Technology: Current Issues. - 2016. - Vol. 8, no. 2. - P. 98-105.

31. Пискунов, А.И. История педагогики и образования от зарождения обучения в первобытном обществе до конца 20-го века: учеб. для пед. училищ. - М.: Сфера, 2001. - 512 c. 


\section{Непрерывное образование в течение жизни}

32. Семенова, А. Московские школь будут давать «перевернутые уроки» / А. Семенова, М. Шаталова. - http://izvestia.ru/news/561316 (дата обращения: 05.04.2019).

33. Schwartz, M. The Flipped Classroom / M. Schwartz. - https://www.ryerson.ca/content/dam/lt/ resources/handouts/flipped_classroom.pdf(дата обращения: 01.05.2019).

34. Schmidt, S.M. The Flipped Classroom: A Twist on Teaching / S.M. Schmidt, D.L. Ralph // Contemporary Issues in Education Research. - 2016. - Vol. 9, no. 1. - P. 1-6.

35. Смолкин, А.М. Активные методы обучения / А.М. Смолкин. - М.: Высш. ик., 1991. - 176 с.

36. Thompson, T. Establishing Communities of Practice for Effective and Sustainable Professional Development for Blended Learning / T. Thompson, H. Kanuka // Effective Blended Learning Practices: Evidence-Based Perspectives in ICT-Facilitated Education: Evidence-Based Perspectives in ICT-Facilitated Education. - 2009. - P. 144-162.

37. Tips for Recording Video for a Flipped Classroom. - https://web.archive.org/web/20150317 193149/http:// ctl.uga.edu/flipping/video-tips (дата обращения: 29.06.2019).

38. Tsytovich, M.V. Pedagogical Assistance to "Lingva" Program Participants Professional Writing Formation at the Elementary Stage of Language Training / М.V. Tsytovich // Вестник ЮУрГУ. Серия «Образование. Педагогические науки». - 2016. - T. 8, №. 2. - C. 41-47.

39. Tsytovich, M.V. Teaching Academic Writing in a Flipped Classroom / M.V. Tsytovich, G.F. Boronenko // Вестник ЮУрГУ. Серия «Образование. Педагогические науки». - 2018. - T. 10, № 2. - C. 59-65.

40. Tsytovich, M.V. Academic Writing Skills of University Teaching Staff Formation at the PreIntermediate Stages of Language Training / M.V. Tsytovich, O.V. Yakusheva // 9th Annual International Conference on Technology, Education and Development. - 2016. - P. 8160-8165.

41. Tucker, B. Flipped Classroom: Online Instruction at Home Frees Class Time for Learning / B. Tucker // Education Next. - 2012. - Vol. 12, no. 1. - P. 82-83.

42. Владимиров, А.В. Методика «перевернутого класса» в реализации требований ФГОС / А.В. Владимиров, Ю.В. Лебедев. - http://gov.cap.ru/SiteMap.aspx?gov_id=121\&id=1919130 (дата обращения: 07.04.2019).

43. Volchenkova, K.N. An Andragogical Approach to Forming Faculty Communication Competence in Foreign Language for International Activities / K.N. Volchenkova // Вестник ЮУрГУ. Серия «Образование. Педагогические науки». - 2015. - T. 7, №. 4. - С. 18-25.

44. Volchenkova, K.N. Peer Observation as a Tool for Teacher's Professional Development and the Way to Increase the Quality of the Education Process / K.N. Volchenkova // Вестник ЮУрГУ. Серия «Образование. Педагогические науки». - 2016. - Т. 8, № 3. - С. 39-44.

45. Выготский, Л.С. Педагогическая психология / Л.С. Выготский; пер. на англ. яз. R. Silverman u $\partial p$. - CRC Press, 1997. - $416 c$.

Цытович Мария Витальевна, кандидат педагогических наук, доцент кафедры иностранных языков, Южно-Уральский государственный университет, г. Челябинск, maria.tsytovich@gmail.com.

Бороненко Галина Фёдоровна, старший преподаватель кафедры иностранных языков, ЮжноУральский государственный университет, г. Челябинск, gboronenko@yandex.ru.

Якушева Оксана Васильевна, кандидат филологических наук, доцент кафедры иностранных языков, Южно-Уральский государственный университет, г. Челябинск, iow74@mail.ru.

Поступила в редакцию 29 мая 2019 2.

\section{ОБРАЗЕЦ ЦИТИРОВАНИЯ}

Цытович, М.В. Использование технологии перевернутого класса на разных ступенях высшего образования / М.В. Цытович, Г.Ф. Бороненко, О.В. Якушева // Вестник ЮУрГУ. Серия «Образование. Педагогические науки». - 2019. - Т. 11, № 3. - C. 21-32. DOI: $10.14529 /$ ped 190302

\section{FOR CITATION}

Tsytovich M.V., Boronenko G.F., Yakusheva O.V. Flipped Classroom Technology and Its Implementation at Various Levels of Higher Education. Bulletin of the South Ural State University. Ser. Education. Educational Sciences. 2019, vol. 11, no. 3, pp. 21-32. DOI: $10.14529 /$ ped 190302 